\title{
Penerapan Pendekatan Contextual Teaching and Learning dalam Meningkatkan Hasil Belajar Matematika pada Materi Luas dan Keliling Bangun Datar
}

\author{
Siti Muflihah, Anerbelson Lepith \\ STKIP Nuuwar Fakfak, Papua Barat \\ Email : 1ychamuf@gmai.com ${ }^{1}$, anerolepith@gmail.com ${ }^{2}$
}

\begin{abstract}
Abstrak
Penelitian ini bertujuan untuk meningkatkan hasil belajar dan siswa terhadap luas dan keliling bangun datar melalui penerapan pendekatan Contextual Teaching and Learning (CTL) siswa kelas V MI AsySyafi'iyah Fakfak. Desain penelitian adalah penelitian tindakan kelas dengan dua siklus yang terdiri dari dua pertemuan per siklus. Setiap siklus terdiri dari perencanaan, pelaksanaan, observasi, dan refleksi. Subjek penelitian adalah siswa kelas V sebanyak 18 orang yang terdiri dari 11 siswa perempuan dan 7 siswa laki-laki. Teknik pengumpulan data menggunakan observasi, tes, catatan lapangan dan evaluasi. Data hasil penelitian menunjukkan adanya peningkatan hasil belajar siswa dilihat dari nilai rata-rata kelas siklus I sebesar 65 dengan ketuntasan klasikal sebesar 55,5\% dan nilai rata-rata siklus II meningkat menjadi 84,4 dengan ketuntasan klasikal sebesar 94,44\%. Berdasarkan hasil analisis data, disimpulkan bahwa pendekatan CTL efektif mengantarkan siswa kearah pembelajaran yang aktif, inovatif, kreatif dan menyenangkan karena pembelajaran dilakukan di luar kelas, siswa menemukan sendiri pengetahuan baru sehingga dapat meningkatkan hasil belajar matematika tentang luas dan keliling bangun datar.
\end{abstract}

Kata Kunci: Contextual Teaching and Learning (CTL), hasil belajar.

\section{The Implementation of Contextual Teaching and Learning Approach to Improve Mathematical Learning Outcomes in Broad Material and Around the Flat Shape}

\begin{abstract}
This study aims to improve student learning outcomes and understanding of flat and wide area measurement through the application of approach of Contextual Teaching and Learning (CTL) fifth grade students of MI Asy-Syafi'iyah Fakfak. The research design is a classroom action research with two cycles consisting of two meetings per cycle. Each cycle consists of planning, implementation and observation, and reflection. The research subjects were 18 grade $V$ students consisting of 11 female students and 7 male students. Data collection techniques use observation, tests, field notes and evaluations. The research data shows an increase in learning outcomes and student understanding seen from the average value of the first cycle class of 65 with classical completeness of $55.5 \%$ and the average value of the second cycle increased to 84.4 with classical completeness of $94.44 \%$. Based on the results of data analysis, it was concluded that the CTL approach effectively leads students towards active, innovative, creative and fun learning because learning is done outside the classroom, students find new knowledge themselves so that they can improve learning outcomes and mathematical understanding.
\end{abstract}

Keyword: Contextual Teaching and Learning (CTL), learning outcomes 


\section{PENDAHULUAN}

International Association for Evaluation of Educational Achievement (IEEA) mempublikasikan hasil penelitiannya tentang tunaaksara siswa 9-14 tahun di 41 negara. Berdasarkan hasil penelitian tersebut, Indonesia menduduki peringkat ke 40 dari 41 negara dan dikategorikan sebagai negara belum maju bersama Afrika Selatan. Sedangkan PISA (Programme for International Student Assesment) merupakan kegiatan tiga tahunan yang bertujuan untuk menguji tingkat literasi membaca, matematika dan sains siswa sekolah berusia 15 tahun, hasil tes pada tahun 2015 Indonesia menempati peringkat ke 69 dari 76 negara yang ikut berpartisipasi (Coughlan, 2015). Tentulah hal ini menunjukan bahwa pendidikan Indonesia masih jauh dari harapan.

Belajar dan pembelajaran merupakan aktivitas yang tidak dapat dipisahkan di dalam pendidikan. Pembelajaran secara sederhana dapat diartikan sebagai upaya untuk membelajarkan seseorang melalui berbagai upaya dan berbagai strategi, metode dan pendekatan ke arah pencapaian tujuan yang telah direncanakan (Majid, 2016). Sedangkan berdasarkan UU SPN No. 20 tahun 2003 pembelajaran adalah proses interaksi antara peserta didik dengan pendidik dan sumber belajar pada suatu lingkungan belajar. Tujuan mata pelajaran matematika salah satunya adalah agar siswa memiliki matematika untuk pemacahan masalah sehari-hari. Kemampuan matematika sangat penting untuk dikembangkan sejak jenjang sekolah dasar karena akan menjadi dasar untuk mengembangkan kemampuan seperti kemampuan mengaplikasikan konsep matematika, penalaran matematika, berpikir kritis, dan pemecahan masalah. Hal ini sejalan dengan Wiharno (dalam Ompusunggu, 2009) yang menyimpulkan bahwa "kemampuan matematika merupakan suatu kekuatan yang harus diperhatikan dan diperlakukan secara fungsional dalam proses dan tujuan pembelajaran, hal tersebut hanya bisa dilakukan melalui pembelajaran dengan pemahaman". Siswa biasanya belajar matematika dengan cara menghafal bukan memahami, materi yang bersifat abstrak membuat siswa kesulitan dalam memahaminya, serta anggapan siswa bahwa matematika merupakan pelajaran yang sulit membuat mereka malas untuk mempelajari dan memahaminya.

Konsep luas dan keliling bangun datar merupakan salah satu kompetensi bagi siswa kelas IV, V, dan VI. Jika melihat bahwa konsep tersebut sudah diberikan sejak kelas IV, seharusnya di kelas V dan VI siswa sudah memiliki kemampuan matematika untuk materi ini. Kenyataan dilapangan bahwa masih didapati siswa yang belum bisa memahami luas dan keliling bangun datar. Hal ini menunjukkan bahwa ternyata meskipun materi luas dan keliling bangun datar sudah diajarkan di tiga tingkatan kelas tetapi siswa belum memahami materi secara komperhensif. 
Salah satu pengaruh rendahnya siswa terhadap pelajaran matematika adalah pendekatan pembelajaran yang dilakukan oleh guru. Masih banyak guru yang menempatkan dirinya sebagai sumber utama pengetahuan kemudian ceramah adalah yang menjadi pilihan utama strategi belajar yang menyebabkan kejenuhan untuk belajar matematika. Slameto (2015) mengungkapkan bahwa "Guru biasanya mengajar dengan metode ceramah saja sehingga siswa menjadi bosan, mengantuk, pasif, dan hanya mencatat saja".

Banyak cara yang dapat dilakukan guru dalam mengajarkan materi pelajaran, salah satunya dengan pendekatan Contextual Teaching and Learning (CTL). Johnson (2002) mengartikan pendekatan CTL adalah suatu proses pendidikan yang bertujuan membantu siswa melihat makna dalam bahan pelajaran yang mereka pelajari dengan cara menghubungkannya dengan konteks kehidupan sehari-hari mereka, yaitu dengan konteks lingkungan pribadinya, sosialnya, dan budayanya.

Untuk dapat memberi dan meningkatkan hasil belajar siswa, penggunaan pendekatan CTL menjadi alternatif melalui penggunaan selama beberapa siklus. Penulis ingin mengetahui apakah penerapan pendekatan CTL dapat meningkatkan hasil belajar matematika siswa pada materi luas dan keliling bangun datar di MI Asy-Syafi'iyah Fakfak. Penelitian ini bermanfaat: (1) Bagi guru, dapat mengetahui penerapan pendekatan CTL sebagai salah satu variasi dalam mengajarkan luas dan keliling bangun datar untuk meningkatkan hasil belajar dan siswa di Kelas V dan (2) Bagi peneliti lain, sebagai sumber informasi untuk mengadakan penelitian lebih lanjut, khususnya mengenai pembelajaran matematika melalui pendekatan CTL.

\section{KAJIAN TEORITIS}

\section{Pendekatan Contextual Teaching and Learning (CTL)}

Pendekatan pembelajaran adalah cara pandang untuk membelajarkan peserta didik melalui pusat perhatian tertentu (Akbar, 2015). Menurut Suherman (1993) pendekatan dalam pembelajaran adalah suatu jalan, cara, atau kebijaksanaan yang ditempuh oleh guru atau siswa dalam pencapaian tujuan pembelajaran dilihat dari sudut bagaimana proses pembelajaran atau materi pembelajaran itu, umum atau khusus. Hal yang sama dikemukakan oleh Wahjoedi (1999) bahwa pendekatan pembelajaran adalah cara mengelola kegiatan belajar dan perilaku siswa agar ia dapat aktif melakukan tugas belajar sehingga dapat memperoleh hasil belajar secara optimal.

Kaitannya dengan pembelajaran matematika, Ruseffendi (Hendriana dkk, 2014) menjelaskan bahwa pendekatan dalam pembelajaran matematika adalah suatu cara atau prosedur yang ditempuh guru dalam pencapaian tujuan pembelajaran dilihat dari sudut bagaimana proses pembelajaran atau materi pembelajaran dikelola. 
Pembelajaran Kontekstual telah berkembang di negara-negara maju dengan nama beragam. Di negara Belanda disebut dengan istilah Realistic Methematics Education (RME) yang menjelaskan bahwa pembelajaran matematika harus dikaitkan dengan kehidupan sehari-hari peserta didik. Di Amerika disebut dengan istilah Contextual Teaching and Learning (CTL) yang intinya membantu guru untuk mengaitkan materi pelajaran dengan kehidupan nyata dan memotivasi peserta didik untuk mengaitkan pengetahuan yang dipelajarinya dengan kehidupan sehari-hari mereka.

The Washington State Consortium for Contextual Teaching and Learning (2001) mengartikan pembelajaran kontekstual adalah pengajaran yang memungkinkan siswa memperkuat, memperluas, dan menerapkan pengetahuan dan keterampilan akademisnya dalam berbagai latar sekolah untuk memecahkan seluruh persoalan yang ada dalam dunia nyata. Pembelajaran kontekstual terjadi ketika siswa menerapkan dan mengalami apa yang diajarkan dengan mengacu pada masalah-masalah riil yang berasosiasi dengan peranan dan tanggungjawab mereka sebagai anggota keluarga, masyarakat, siswa, dan selaku pekerja.

Tabel 1. Fase-fase Pembelajaran CTL

\begin{tabular}{|c|c|}
\hline Fase & Kegiatan Guru \\
\hline $\begin{array}{l}\text { Fase 1: } \\
\text { Mengembangkan pemikiran siswa } \\
\text { untuk melakukan kegiatan belajar } \\
\text { bermakna, apakah dengan cara } \\
\text { sendiri, menemukan sendiri dan } \\
\text { mengkonstruksi sendiri } \\
\text { pengetahuan dan keterampilan baru } \\
\text { yang harus dimilikinya. }\end{array}$ & $\begin{array}{l}\text { Membagikan beberapa lembar kertas kepada siswa, } \\
\text { dan meminta untuk dibuat beberapa bentuk bangun } \\
\text { datar sederhana yang siswa ketahui. }\end{array}$ \\
\hline $\begin{array}{l}\text { Fase 2: } \\
\text { Melaksanakan sejauh mungkin } \\
\text { kegiatan inquiri }\end{array}$ & $\begin{array}{l}\text { Dengan berbantuan bangun datar yang telah dibuat } \\
\text { siswa, guru meminta pada siswa untuk memberi nama } \\
\text { pada masing-masing bangun datar yang telah dibuat } \\
\text { sebelumnya. }\end{array}$ \\
\hline $\begin{array}{l}\text { Fase } 3 \text { : } \\
\text { Mengembangkan sifat ingin tahu } \\
\text { siswa melalui memunculkan } \\
\text { pertanyaan }\end{array}$ & $\begin{array}{l}\text { Mengajak siswa untuk keluar kelas dan membentuk } \\
\text { lingkaran di halaman sekolah (lapangan upacara) dan } \\
\text { memancing siswa untuk bertanya. }\end{array}$ \\
\hline $\begin{array}{l}\text { Fase 4: } \\
\text { Menciptakan masyarakat belajar, } \\
\text { seperti melalui kegiatan kelompok } \\
\text { diskusi, tanya jawab dan } \\
\text { sebagainya }\end{array}$ & $\begin{array}{l}\text { Membagi siswa dalam beberapa kelompok yang } \\
\text { beranggotakan } 4-5 \text { orang, dan membagikan } \\
\text { permasalahan berkaitan dengan materi luas dan } \\
\text { keliling bangun datar. }\end{array}$ \\
\hline
\end{tabular}




\begin{tabular}{|c|c|}
\hline Fase & Kegiatan Guru \\
\hline $\begin{array}{l}\text { Fase } 5 \text { : } \\
\text { Menghadirkan model sebagai } \\
\text { contoh pembelajaran }\end{array}$ & $\begin{array}{l}\text { Mendatangkan model (misalnya) tukang yang biasa } \\
\text { memasang ubin ruangan, dan memberikan kesempatan } \\
\text { untuk menjelaskan pemakaian kebutuhan ubin pada } \\
\text { ukuran lantai yang akan dipasang ubin. }\end{array}$ \\
\hline $\begin{array}{l}\text { Fase 6: } \\
\text { Membiasakan anak untuk } \\
\text { melakukan refleksi dari setiap } \\
\text { kegiatan pembelajaran yang telah } \\
\text { dilakukan }\end{array}$ & $\begin{array}{l}\text { Memberikan kesempatan pada siswa untuk } \\
\text { menyampaikan pendapatnya terkait dengan } \\
\text { pembelajaran yang telah dilaksanakan. }\end{array}$ \\
\hline $\begin{array}{l}\text { Fase 7: } \\
\text { Melakukan penilaian secara } \\
\text { objektif, yaitu melalui kemampuan } \\
\text { yang sebenarnya pada setiap siswa }\end{array}$ & $\begin{array}{l}\text { 1) Masing-masing kelompok mempresentasikan hasil } \\
\text { diskusinya dan kelompok lain memberikan } \\
\text { tanggapan. } \\
\text { 2) Siswa mengerjakan soal evaluasi yang telah } \\
\text { disediakan oleh guru. }\end{array}$ \\
\hline
\end{tabular}

Sumber :Tim pengembang MKDP (2012)

\section{Hasil Belajar}

Belajar adalah suatu proses usaha yang dilakukan seseorang untuk memperoleh suatu perubahan tingkah laku sebagai hasil pengalamannya sendiri dalam interaksi dengan lingkungannya (Slameto, 2013). Menurut Gagne (Susanto, 2016), belajar dapat didefinisikan sebagai suatu proses di mana suatu organisme berubah perilakunya sebagai akibat pengalaman. Belajar merupakan suatu proses untuk memperoleh motivasi dalam pengetahuan, keterampilan, kebiasaan, dan tingkah laku. Gagne juga menekankan bahwa belajar sebagai suatu upaya memperoleh pengetahuan atau keterampilan melalui instruksi.

Hasil belajar merupakan hasil yang dicapai siswa setelah mengikuti proses pembelajaran. Hasil belajar siswa pada hakikatnya merupakan perubahan tingkah laku siswa setelah melalui proses belajarmengajar. Sebagaimana dijelaskan oleh Susanto (2016) menerangkan bahwa hasil belajar adalah perubahan-perubahan perilaku yang terjadi pada siswa, baik yang menyangkut aspek kognitif, afektif dan psikomotor. Sejalan dengan hal tersebut Purwanto (2013) mengatakan bahwa proses belajar dapat melibatkan aspek kognitif, afektif dan psikomotor, hasil belajar dapat dilihat dari nilai tes siswa, lembar penilaian afektif dan psikomotor. Hasil belajar juga merupakan istilah yang sering digunakan untuk menunjukkan tingkat keberhasilan yang dicapai seseorang setelah melakukan usaha tertentu yang diperoleh melalui sebuah kegiatan belajar mandiri atau kegiatan belajar mengajar. Dalam hal ini, hasil belajar adalah hasil yang dicapai siswa dalam bidang studi tertentu setelah mengikuti proses pembelajaran. 


\section{METODE}

Jenis penelitian tindakan kelas ini mengacu pada model Kemmis dan Mc. Taggart terdiri atas empat tahap yaitu perencanaan, pelaksanaan tindakan, observasi dan refleksi. Dalam penelitian ini, peneliti adalah instrumen utama karena peneliti yang merencanakan, merancang, melaksanakan, mengumpulkan data, menganalisis data, menarik kesimpulan, dan membuat laporan. Penelitian ini dilakukan pada semester II Tahun Pelajaran 2017/2018. Subjek penelitian ini adalah 18 siswa Kelas V MI Asy-Syafi'iyah Fakfak yang meliputi 7 siswa laki-laki dan 11 siswa perempuan.

Jenis data dalam penelitian ini berupa data kuantitatif yaitu data yang diperoleh dari tes yang diberikan kepada siswa kemudian diolah penentuan skornya dan mengkonversi perolehan persentase tersebut sesuai dengan kriteria penilaian yang dikembangkan oleh Arikunto (2008) sebagai berikut:

$81 \%-100 \%$ : Sangat Baik

$61 \%-80 \%$ : Baik

$41 \%-60 \%$ : Cukup

$21 \%-40 \%$ : Kurang

$<$ dari $20 \%$ : Sangat Kurang.

Penelitian tindakan kelas ini dikatakan berhasil apabila telah memenuhi indikator keberhasilan pembelajaran yaitu siswa yang tuntas telah mencapai $>75 \%$.

\section{HASIL DAN PEMBAHASAN}

\section{Hasil Penelitian}

Hasil penelitian ini terbagi dalam dua bagian, yaitu (1) hasil pra tindakan, dan (2) hasil pelaksanaan tindakan. Kegiatan pada pra tindakan yaitu peneliti memberikan tes awal kepada siswa yang diikuti oleh 18 siswa. Tes awal ini bertujuan untuk mengetahui tingkat pengetahuan siswa tentang materi prasyarat dari luas dan keliling bangun datar dan juga untuk pembentukan kelompok secara heterogen. Materi yang diberikan pada tes awal yaitu soal cerita tentang luas dan keliling bangun datar. Berdasarkan hasil analisis tes awal, diperoleh kesimpulan bahwa sebagian besar siswa belum dapat memahami cara menghubungkan antar satuan. Hal ini terjadi karena siswa belum memahami konsep luas dan keliling itu sendiri. Meski ada beberapa siswa sudah dapat memahami konsep luas dan keliling bangun sederhana.

Pelaksanaan tindakan dalam penelitian ini terbagi menjadi dua siklus, yaitu siklus I dan siklus II. Setia siklus terdiri dari dua pertemuan. Kegiatan pada pertemuan pertama, yaitu 
peneliti memberikan materi memahamiluas bangun datar, sedangkan pada pertemuan kedua peneliti materi menghitung luas dan keliling bangun datar sederhana.

Selama pembelajaran berlangsung dilakukan pengamatan aktivitas guru. Pengamatan dilakukan oleh dua pengamat. Pembelajaran diakhiri dengan pemberian tes akhir di setiap siklus untuk mengetahui hasil belajar siswa apakah sudah tuntas.

\section{Siklus I}

Kegiatan Siklus I dilaksanakan selama dua pertemuan, pertemuan pertama sebagai awal dari penelitian dilaksanakan pada hari Selasa tanggal 18 September 2018, sedangkan pertemuan kedua pada tanggal 20 September 2018. Adapun peningkatan hasil belajar dan siswa terhadap matematika pada materi memahami luas dan keliling bangun datar sederhana pada siklus I diperoleh hasil sebagai berikut.

Tabel 2. Rekapitulasi Tes Akhir Pra Siklus dan Siklus I

\begin{tabular}{rccc}
\hline \multirow{2}{*}{ No } & \multirow{2}{*}{ Siswa } & \multicolumn{2}{c}{ Nilai } \\
\cline { 3 - 4 } & & Pra Siklus & Siklus I \\
\hline 1 & NAD & 80 & 90 \\
2 & AA & 70 & 80 \\
3 & SAK & 60 & 70 \\
4 & MSAP & 40 & 50 \\
5 & AHO & 70 & 90 \\
6 & MFR & 50 & 70 \\
7 & PMM & 40 & 50 \\
8 & MK & 40 & 50 \\
9 & SN & 60 & 70 \\
10 & AMI & 40 & 50 \\
11 & FRM & 50 & 50 \\
12 & SHH & 40 & 40 \\
13 & ARN & 60 & 80 \\
14 & SFD & 40 & 50 \\
15 & MSSN & 40 & 70 \\
16 & FW & 40 & 60 \\
17 & LS & 40 & 70 \\
18 & VS & 50 & 80 \\
Jumlah & 910 & 1170 \\
Mean & 50,56 & 65,00
\end{tabular}

Berdasarkan tes hasil belajar pada gambar di atas menunjukkan bahwa terjadi peningkatan baik pada rata-rata kelas maupun persentase ketuntasan klasikal. Ketuntasan klasikal pada pra siklus $16,6 \%$ dan pada siklus I meningkat menjadi $55,5 \%$.

Selama penelitian berlangsung, terdapat beberapa kelemahan dalam pelaksanaannya yaitu: 1) Pada kegiatan fase 1, guru belum maksimal dalam mengarahkan siswa pada kegiatan mengkonstruksi sendiri pengetahuan dan keterampilan barunya padahal untuk konsep bangun 
datar mereka sudah pernah mendapatkannya di kelas IV, 2) Kegiatan fase 5, ketika mengungkapkan pendapat atau belum berjalan sesuai yang diharapkan, hal ini dikarenakan siswa masih malu-malu dalam mengajukan pertanyaan kepada modeling, 3) Pembelajaran CTL memerlukan waktu yang relatif lama karena proses pembelajaran dilakukan diluar kelas terlebih dahulu, untuk mengantarkan siswa pada keadaan yang riil.

Berdasarkan beberapa kelemahan tersebut, maka diperlukan perumusan solusi terhadap kendala yang terjadi dilapangan bertujuan agar siklus berikutnya diperoleh hasil yang lebih baik,solusi tersebut yaitu:1) Guru mengarahkan siswa pada kegiatan mengkonstruksi sendiri pengetahuan dan keterampilan barunya padahal untuk konsep bangun datar melalui contoh bentuk-bentuk bangun ruang melalui gambar yang kemudian meminta siswa untuk mengaplikasikan bentuk tersebut dengan pada media kertas yang telah dibagikan, 2) memotivasi siswa untuk melakukan tindakan aktif dalam mengajukan pendapat ataupun pertanyaan kepada model yang dipilih atau ditampilkan oleh guru, 3) Alokasi waktu dan manajemen pengelolaan RPP harus diperhitungkan atau dipersiapkan secara tepat.

\section{Siklus II}

Kegiatan Siklus II dilaksanakan selama dua pertemuan, pertemuan pertama sebagai awal dari penelitian dilaksanakan pada hari Selasa tanggal 25 September 2018, sedangkan pertemuan kedua pada tanggal 27 September 2018. Adapun peningkatan hasil belajar dan siswa terhadap matematika pada materi luas dan keliling bangun datar sederhana pada siklus II diperoleh hasil sebagai berikut.

Tabel 3. Rekapitulasi Tes Akhir Siklus I dan Siklus II

\begin{tabular}{rccc}
\hline \multirow{2}{*}{ No } & \multirow{2}{*}{ Siswa } & \multicolumn{2}{c}{ Nilai } \\
\cline { 3 - 4 } & & Siklus I & Siklus II \\
\hline 1 & NAD & 90 & 100 \\
2 & AA & 80 & 100 \\
3 & SAK & 70 & 100 \\
4 & MSAP & 50 & 80 \\
5 & AHO & 90 & 100 \\
6 & MFR & 70 & 80 \\
7 & PMM & 50 & 70 \\
8 & MK & 50 & 70 \\
9 & SN & 70 & 90 \\
10 & AMI & 50 & 70 \\
11 & FRM & 50 & 80
\end{tabular}




\begin{tabular}{cccc}
12 & SHH & 40 & 50 \\
13 & ARN & 80 & 100 \\
14 & SFD & 50 & 70 \\
15 & MSSN & 70 & 80 \\
16 & FW & 60 & 80 \\
17 & LS & 70 & 100 \\
18 & VS & 80 & 100 \\
\multicolumn{2}{c}{ Jumlah } & 1170 & 1520 \\
\multicolumn{2}{c}{ Mean } & 65,00 & 84,44
\end{tabular}

Berdasarkan tes hasil belajar pada tabel di atas menunjukkan bahwa terjadi peningkatan baik pada rata-rata kelas maupun persentase ketuntasan klasikal. Ketuntasan klasikal pada kegiatan siklus I55,5\% dan pada siklus II meningkat menjadi 94,44\%.

\section{Pembahasan}

Peningkatan rata-rata hasil belajar matematika siswa kelas V MI Asy-Syafi'iyah pada materi luas dan keliling bangun datar disajikan dalam diagram 1 berikut.

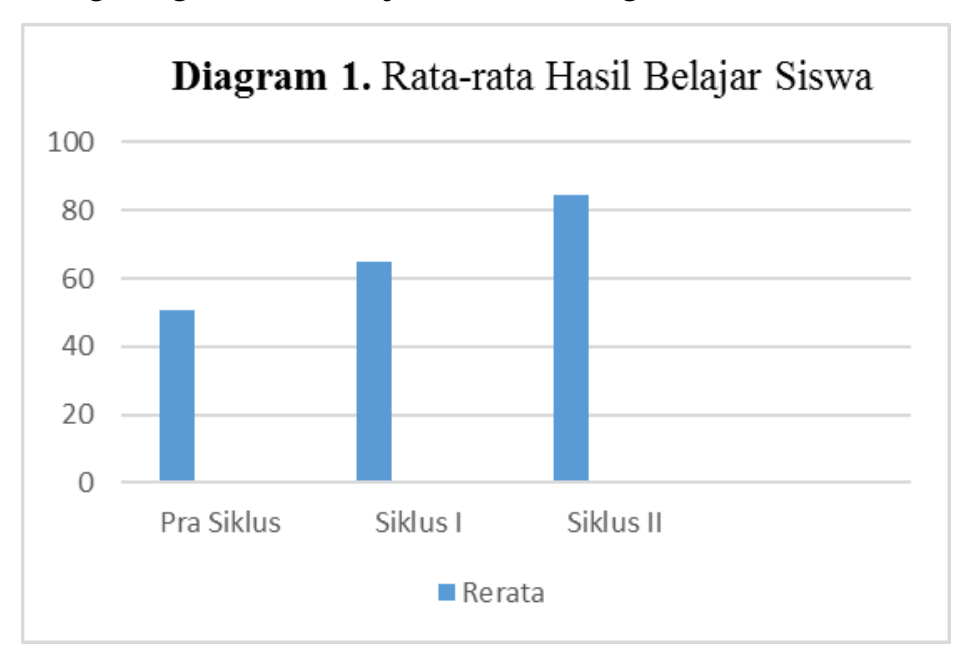

Berdasarkan gambar diagram 1 tersebut, menunjukan bahwa perolehan nilai siswa antara pra siklus 50,56 di Siklus I terjadi peningkatan menjadi 65,0 dan meningkat lagi di siklus II menjadi 84,44. Itu berarti bahwa nilai rata-rata tersebut telah mencapai diatas KKM yang ditentukan oleh sekolah yaitu sebesar 62,00. Hal ini karena pendekatan CTL telah mampu mengaktifkan pengetahuan yang sudah dimiliki siswa sebelumnya, melalui pembelajaran CTL yang dilakukan sendiri oleh siswa diluar kelas telah dapat membantu siswa dalam rangka memperoleh pengalaman dan pembelajaran baru. 
Hal tersebut membuktikan bahwa model pembelajaran CTL dapat meningkatkan hasil belajar siswa. Sebagaimana hasil penelitian Leksair (2017) yang menyimpulkan bahwa melalui model pembelajaran CTL dapat membuat pembelajaran menjadi aktif dan dapat meningkatkan hasil belajar siswa.

\section{SIMPULAN DAN SARAN}

Berdasarkan paparan data dan pembahasan, dapat disimpulkan bahwa Penerapan pendekatan CTL dapat meningkatkan hasil belajar siswa tentang luas dan keliling bangun datar siswa Kelas V MI Asy-Syafi'iyah Fakfak yang terlihat dari semakin meningkatnya hasil belajar siswa pada siklus II dibanding dengan siklus I. Rata-rata hasil tes pada siklus I yaitu 65,0 dengan ketuntasan klasikal 55,5\% (10 anak) dan rata-rata pada siklus II yaitu 84,44 dengan ketuntasan klasikal 94,44\% (17 anak). Penerapan pendekatan CTL yang dilaksanakan dengan cara pembentukan kelompok dan proses belajarnya di halaman sekolah menjadikan siswa aktif dalam menemukan pengetahuan baru sendiri, jika terdapat siswa yang mengalami kesulitan, teman dalam satu kelompok akan memberikan bantuan terhadap teman sekelompoknya. Ketika memecahkan masalah masing-masing siswa memperoleh yang lebih mantap.

Berdasarkan hasil dan pembahasan penelitian tersebut, penulis menyarankan bagi peneliti lain yang akan menindaklanjuti penelitian ini disarankan untuk mengurangi kelemahankelemahan dalam penelitian ini, diantaranya adalah efisiensi waktu pembelajan, pengelolaan kelas, agar dapat mengarahkan siswa ke arah pembelajaran yang aktif, inovatif, kreatif, efektif dan menyenangkan.

\section{DAFTAR PUSTAKA}

Akbar, S. (2015). Instrumen Perangkat Pembelajaran. Bandung: PT Remaja Rosdakarya.

Arikunto, S. (2008). Dasar-Dasar Evaluasi Pendidikan. Jakarta: Prestasi Pusaka.

Coughlan, S. (2015, Mei 13). Asia peringkat tertinggi sekolah global, Indonesia nomor 69. Retrived

Direktorat Pendidikan Lanjutan Petama Depdiknas. (2003). Pembelajaran Kontekstual. Jakarta: Depdiknas.

Hendriana, Heris \& Soemarmo, U. (2014). Penilaian Pembelajaran Matematika. Bandung: PT Refika Aditama.

Hudojo, H. (1998). Belajar Mengajar Matematika. Jakarta : Depdikbud.

Johnson, E. B. (2002).Contextual Teaching and Learning: What it is and Whay it's Here to Stay. California: Corwin Press.

Leksair, M, A. (2017). Peningkatan Hasil Belajar Matematika melalui Model Pembelajaran CTL. Jurnal Pendidikan Guru SD, 06 (09), 880-886.

Majid, A. (2016). Strategi Pembelajaran. Bandung: PT Remaja Rosda Karya.

McTaggart, R. (1991). Action Research A Short Modern History. Victoria. Australia: Deakin University. 
Ompusunggu, V.D.K. (2014). Peningkatan Kemampuan Matematik dan Sikap Positif Terhadap Matematika Siswa Smp Nasrani 2 Medan Melalui Pendekatan Problem Posing. Saintech, 06 (04), 93-105.

Purwanto, N. (2002). Ilmu Pendidikan dan Teknis. Bandung: Rosda Karya.

Republik Indonesia. (2003). Undang-undang No. 20 Tahun 2003 tentang Sistem Pendidikan Nasional. Sekretariat Negara. Jakarta.

Slameto. (2015). Belajar \& Faktor-Faktor Yang Mempengaruhinya. Jakarta: PT. Rineka Cipta.

Suherman. (1993). Strategi Belajar Mengajar Matematika. Jakarta: Universitas Terbuka.

Susanto, A, (2016). Teori Belajar dan Pembelajaran. Jakarta: Prenadamedia Group.

Suyono, \& Hariyanto. (2016). Belajar dan Pembelajaran. Bandung: PT Remaja Rosda Karya.

Tim Pengembangan MKDP. (2002). Kurikulum dan Pembelajaran. Jakarta: Rajawali Pers.

Wahjoedi. (1999). Jurnal IPTEK Olah Raga. Jurnal. Jakarta: Pusat Pengkajian dan Pengembangan IPTEK. 